\title{
Problems and Innovations in the Teaching Reform in Colleges and Universities
}

\author{
Xing Zhongchen ${ }^{1}$, Wang Rui ${ }^{2}$ \\ ${ }^{1}$ Dept. of Information Operation, Dalian Naval Academy, Dalian, Liaoning, 11608,China \\ ${ }^{2}$ Dept. of Communication, Dalian Naval Academy, Dalian, Liaoning, 11608,China \\ yuezhiying@yeah.net
}

\begin{abstract}
The rapid development of society and economy has put forward higher and more diversified requirements for the cultivation of higher talents. This urgently needs that colleges and universities adopt effective reform measures to further deepen the teaching reform, adjust the teaching contents in time, and update the teaching means to improve the ability and level of talent cultivation. However, due to some historical reasons, the teaching reform of colleges and universities is faced with many difficulties and problems. Therefore, only to find out the main problems in teaching and the resistance of teaching reform, it can break the old model of teaching, clear the direction of teaching reform. To this end, the existing problems in the reform of teaching methods and innovation are studied.
\end{abstract}

Keywords: colleges and universities; teaching reform; teaching mode; talent training; innovation

\section{Introduction}

Talent training, scientific research, social service, cultural heritage innovation are the four major functions of colleges and universities, where talent training is the most fundamental function of colleges and universities. And talent training mainly relies on teaching, so the teaching quality is the key to improving the quality of talent training [1-2]. However, there are many problems in China's colleges and universities, such as backward educational ideas, single teaching methods, outdated teaching contents, uneven teaching resources, imperfect teaching management system and unreasonable teaching evaluation system, etc., leading to the questioned quality of talent training by the public [3 -4]. Therefore, with the development of China's higher education popularization, how to deepen the reform of teaching quality, improve the quality of talent training in colleges and universities, promote the development of colleges and universities, and take the characteristics road are the important topics that colleges and universities need to be solved urgently [5-6].

In view of the above, we have studied the problems and innovations in the reform of university teaching. First of all, the current problems in university teaching are analyzed, and then to understand the resistance of teaching reform in colleges and universities. Secondly, the direction and hotspots of teaching reform and innovation in colleges and universities are studied. Teaching is the core work of colleges and universities, is the key to university talent training. With the development of social economy and science and technology, the demand, knowledge structure, character quality of talents in colleges and universities have undergone tremendous changes. To cultivate talents with adaptability and innovation ability, colleges and universities must constantly optimize the goal of talent training, carry out the necessary teaching reform and innovate the talent training mode. Among them, the teaching system reform is the most important point of talent training.

\section{The Main Problems in the Reform of Teaching in Colleges and Universities}

At present, the development trend of Chinese universities has gradually from the extension construction and scale expansion to the connotation construction and quality improvement. In recent years, the rapid expansion of university scale and the improvement of teaching quality have made great contributions to the sustainable development of China's economy and society. However, the cultivation of higher talent in the early teaching reform still cannot fully meet the needs of society, the main reason is that there are still several problems in the reform of higher education.

\subsection{The current problems in teaching in colleges and universities}

(1) The traditional concept of teaching has seriously lagged behind the pace of education reform

The traditional teaching ideas think that knowledge is the conclusion and dogma, the study is simply as the input 
process of knowledge from outside to inside; teachers or students' opinions are relatively old and narrow, teachers lack the spirit of equal dialogue with the students; teachers do not really recognize the teaching idea of "give a man a fish, and you have fed him for today", or do not have to implement the concept in teaching; teacher is the absolutely dominant in teaching process, students lacks skepticism and critical attitude towards teachers and books. This kind of closed education idea makes the students cultivated in colleges and universities become the unemployed people who have just graduated. The traditional teaching concept has seriously lagged behind the pace of teaching reform in colleges and universities, which binds the healthy development of higher education.

(2) The old teaching content has been unable to meet the needs of students in all-round development

Due to some historical problems, colleges and universities generally exist the phenomenon of unreasonable professional setting and disciplinary structure, these phenomena may become obstacles to the development of old disciplines, and these old disciplines have become the huge obstacles to declare new professions and impart new knowledge, such a vicious cycle will seriously restrict the healthy development of new and old disciplines. Some old disciplines and old teaching content has been completely unable to meet the needs of students in all-round development, teaching content is single fixed, cross-duplication, fragmented or rigid dogma, which has clearly failed to keep up with the pace of development of the times. Most of the teachers in the teaching process focus on the teaching of the theoretical knowledge and the content of the book, however the practical ability of students and the cultivation of innovative spirit become a slogan or form, it is difficult to carry out substantive work, so the most training of students are with high scores and low abilities, which Cannot adapt to the new situation of China's economic development.

(3) The opposition between teaching and learning is no longer suitable for the training mode of new talents

Teachers are the core force to promote the teaching reform. However, many teachers still lack the activities of teaching innovation because of the subjective and objective aspects. They still follow the traditional teaching methods of "teacher teaching + writing on the blackboard". The teacher pays attention to teaching content thoroughly and thoroughly, but does not pay attention to open students' self-thinking; Teachers lead the teaching process, students can only passively accept, the classroom is lack of interaction between teachers and students. In the traditional classroom, the teacher's teaching goal is to get students good grades, and students' learning goal is to acquire knowledge through curriculum study. Therefore, many university classroom is still "teacher teaches and the students to listen to teachers, teacher reads and students make the notes, and teacher assigns the key and the students to recite ", thus, a phenomenon of "students take notes in class, read the notes after class, recite the notes before exam, and forget all after examination " occurs. Examination results often have a good situation, students get high scores, both teachers and students make benefit. However, students who follow this model do not have the ability to participate in consciousness and innovation, and cannot play their learning initiative. This kind of completely confrontation of teaching and learning has been unable to adapt to the new talent training mode, it must be unified, to make the teaching and learning reform.

(4) The simplification of teaching methods and means deviates from popular education

The rapid development of modern science and technology has enriched the advanced teaching methods. Some universities have invested a lot of money, with modern means of science and technology to establish a modern multimedia classroom to enrich the single teaching means of "blackboard + chalk". But if the teachers do not use the new teaching methods properly, the teaching effect will be even more unsatisfactory. The following problems often arise in the process of using advanced teaching methods: Some teachers just move the text that should be written on the blackboard to the computer screen directly, and do not play the functions of the computer sound, image and animation; some teachers rely too much on multimedia teaching. In the course of teaching, they pay more attention to the broadcast of PPT, but less interaction with students; some teachers use multimedia teaching to provide more information than students can accept. Higher education has entered the stage of popularization, and schools must change the training mode of students from singleness to pluralism according to the needs of social pluralism. Therefore, there are many phenomena and problems in the classroom teaching of colleges and universities which are opposite to the goals of teaching reform, which often causes the new talented person training goal of adapting social need and having the innovation spirit to fall through. In order to give full play to the important role of classroom teaching in personnel 
training, it is imperative to carry out a comprehensive reform of traditional teaching and learning.

\subsection{The source of resistance in teaching reform in colleges and universities}

To enhance the innovation ability of colleges and universities, we must overcome the problems in teaching reform, and the primary task is to recognize the resistance to the teaching reform from the parties to identify the focus of teaching methods of innovation. But to break the traditional teaching ideas and teaching models, and update and change, it will inevitably encounter from all aspects of the obstacles and resistance.

\subsubsection{The school does not pay enough attention to the practitioners of teaching reform}

Although the teaching work is recognized as the central work of the school, teaching reform has also been listed as the focus of the school, but for many reasons, the central position of teaching has been seriously affected, and there are many problems in teaching reform. These problems are mainly reflected in: the school pays attention to the language, but despises the teaching in practice, and generally pays attention to research but despises teaching; teacher assessment is related to professional reward and academic achievement, not to teaching level and so on. This kind of actual situation leads to that many teachers will take a lot of time and energy on scientific research, excessive squeeze teaching time, and teaching reform is difficult to form a large climate in colleges and universities. At the same time, school administrators focus on the professional skills of teachers, encourage teachers to strive for funding, while teaching exploration is difficult to get the school's substantive support and encouragement, which greatly dampen the teachers' initiative to explore new teaching methods and teaching reform.

\subsubsection{Changes in the management system of colleges and universities lag behind the teaching reform}

In the management system of colleges and universities, the school emphasizes the standardization, digitization and procedure of teaching, and often evaluates the teaching level of teachers of different majors and different courses with simple and unified stylized standards. Teachers will inevitably worry about the reform of teaching methods or innovation to lead to the failure of their assessment. As a result, there are too many worries about trying new teaching methods, and they can only continue to use the old methods under these concerns. Rigid management system emphasizes the standardization, rigor and procedural of teaching, but lacks of reasonable blend and flexibility; in the system management, there is no incentive mechanism to improve the initiative and spontaneity of teachers' teaching reform; the evaluation mechanism of teaching method lacks of scientific and flexibility; teaching content is lack of relevance and effectiveness, etc., the current management system and its supporting mechanism seriously lagging behind the process of teaching reform.

\subsubsection{The core role of teaching reform - teachers lack the motivation for reform}

Although college teachers are researchers in a certain field, they have received more intensive professional training, they have little knowledge of the basic theory of education, the forefront teaching methods and the development trend of University courses. Schools ignore the promotion of teaching reform, so that teachers in the reform of teaching methods in psychological preparation is inadequate, the ability to exercise is not enough, as the core role of teaching reform, teachers lack of motivation for teaching reform. Teaching reform not only requires teachers to invest more time and energy in teaching, but also needs the strong support and encouragement of the school, as well as the active cooperation and participation of students. The process of teaching reform is a try process, the reform process may be a failure, and this possibility makes that the teachers have a psychological fear to reformation and innovation of teaching methods, it is not easy to do self-breakthrough in the process of teaching.

\subsubsection{Students lack Initiative in the cooperation of teaching reform}

After the popularization of higher education, the requirements of the school for the students' cultural level, reading and writing ability and comprehensive quality are decreasing, so some of the students themselves do not have the appropriate ability to meet the quality of teaching reform, or, although some students have the ability, they don't have subjective willingness to cooperate, which subjects to certain obstacles. At the same time, from the beginning of school education, students are accustomed to "immersion" teaching method, in the process of acceptance of knowledge it has formed a mindset and learning inertia, some even hate the independent thinking and research work, lack of initiative and enthusiasm in teaching reform. While, teachers' innovative teaching methods require students to study research or 
team activities, which requires students to invest more in learning, self-challenge and self-improvement. These new requirements in the process of teaching reform not only bring opportunities for university to create new students, but also increase the difficulty of teachers to reform teaching methods.

\section{The Direction and Hotspot of Teaching Reform and Innovation in Colleges and Universities}

\subsection{To create a policy environment conducive to teaching reform}

A favorable and relaxed policy environment is an important basis and prerequisite for teaching reform. This requires the state, local governments, colleges and universities must pay attention to the active construction of the policy environment to carry out teaching reform, do the top of the teaching reform design, the specific performance is as in the following areas:

\subsubsection{To extensively carry out educational ideas and discussions, and realize the transformation of educational} ideas

Thought is the guide of action, and scientific concept of education and teaching reform is the guarantee of successful teaching reform. Therefore, the state and local governments should attach great importance to the teaching reform of colleges and universities, and promote the transformation of the concept of education and teaching in colleges and universities. Through the national teaching conference, the teaching evaluation of undergraduate colleges, the study of foreign advanced teaching ideas, the implementation of expert seminars, a large number of field interviews, the establishment of teaching reform pilot areas, and it actively verifies the scientific and feasibility of teaching theory, to provide theoretical guidance and practical experience for teaching reform of colleges and universities, and create a conducive to the public opinion and social atmosphere of promoting the teaching reform. The colleges and universities should actively respond to the call of the state and local governments, and actively organize the school staff and workers to seriously study the spirit of teaching reform and implement them, and effectively change the educational concept of all faculty and staff, and actively encourage faculty members to emancipate their minds, courage to practice, to make preparatory work for the implementation of teaching reform, and eliminate the mood and attitude of part of the staff to resist the reform. At the present stage of university teaching reform process, colleges and universities should establish the concept of quality education of people-oriented into all the staff, for free and all-round development of students.

\subsubsection{The development of university charter should highlight the central position of teaching}

As a carrier of the modern university system with Chinese characteristics, the university charter is the charter of all the work of colleges and universities. It is the guarantee of the university according to the law and the realization of the self-management. It is the basic requirement that colleges and universities realize the modernization of governance system and governance ability. The main leaders of colleges and universities should attach great importance to the construction and approval of the university charter, establish a sense of urgency and responsibility, put the promotion of higher education reform in a prominent position, in particular, and highlight the internal governance structure of the system. As the central content of improving the internal management system of university, it should further strengthen the teaching reform and teaching quality management in the formulation of university constitution. Specifically, it is necessary to follow the "teacher and students- oriented" concept, listen a wide range of opinions for the parties, to make in-depth analysis and demonstration for the existing teaching management system, delete the contents of substandard, and revise the normative place. It truly makes the systematic, standardized and scientific teaching management system, so that other management systems serve the teaching management system, the enhancement of teaching quality and the improvement of personnel training.

\subsubsection{School leaders should attach importance to the co-ordination and leadership of teaching reform}

As the real implementer of teaching reform, colleges and universities have full responsibility and obligation to teaching reform. This requires "school leaders to attach importance to teaching work, make it as the school's regular central work, and the teaching reform is as the core of the reform." That is, the school leaders should pay attention to the co-ordination and leadership of teaching work. In each of the convening of the party committee, the leadership team executive meeting, the annual teaching work plan and summary report and other public meetings, the teaching work is made as the focus of the work highlights. The main leaders of the school should take the initiative to take the lead in 
undertaking the research and practice of related teaching items; regularly held teaching work special meeting, listen carefully to the various departments of teaching reform implementation and the plan and progress of implementation, to determine the focus of next stage of teaching work; take the initiative to lead the relevant disciplines experts to study, research, such as through study abroad, to strengthen inter-school exchanges and cooperation, etc., to demonstrate the scientific and feasibility of teaching reform program. In short, the school leaders should effectively establish the central position of teaching reform, to strengthen the coaching, leadership and supervision of teaching reform.

\subsubsection{To stimulate the enthusiasm of all teachers and students to actively participate in the reform}

After the school leaders do a good job of teaching reform top-level design, it also needs the close cooperation of all the teachers and students. First of all, it is to carry out the ideological reform of teaching reform, to create a good public opinion guide for teaching reform. Secondly, it should start from two aspects of teaching and learning. In the area of teachers, it can send excellent young teachers to study abroad and study advanced foreign teaching ideas and teaching methods. For those teachers who actively participate in the reform and achieve the effectiveness of teaching reform, they should give preferential policies in the evaluation and professional title assessment at the end of the year. In student learning, in order to create a policy environment conducive to students learning, in addition to ensuring normal teaching activities, students should also be provided with a more diverse forms of learning, such as, college students can build self-learning center, and actively guide students to self-learning; stimulate students enthusiasm for extracurricular learning, through a variety of competitions; actively organize students to carry out the second classroom activities, to build a more lively and diverse campus culture and so on. In short, it is to create all teachers and students to actively participate in and with the teaching reform, which is an important guarantee for the smooth implementation of teaching reform.

\subsection{To formulate rules and regulations conducive to teaching reform}

The scientific and reasonable teaching system of rules and regulations is the guarantee for institutionalization, standardized and scientific teaching management system, the theoretical basis for guiding the teaching reform, the realistic basis for the treatment of teaching reform, the premise of self-management, self-development and self-restraint mechanism. Therefore, it is necessary to perfect the rules and regulations for teaching reform and teaching management.

\subsubsection{Reasonable formulation of teaching reform plan}

Reasonable teaching reform plan is an important prerequisite to ensure the smooth progress of teaching reform, teaching reform planning should be developed by the faculties, because the teaching reform content of different disciplines is different, it must be focused, to highlight the characteristics. Therefore, the teaching reform plan should be based on the plan for the development of school education and formulate more detailed and reasonable rules for implementation. First of all, the teaching reform and development planning should be based on the characteristics and laws of the development of disciplines, according to local conditions, due to time, to reflect the elastic characteristics or flexibility characteristics of the planning; Secondly, the teaching reform planning of discipline must be close to local economic and social development, to make teaching reform to serve the regional economic and social development. Finally, the formulation of the teaching reform and development plan should be based on extensive investigation, scientific proof and multi-party participation and consultation, so as to ensure the scientific and feasibility of the teaching reform plan.

\subsubsection{To establish a multi-party consultation system for teaching reform}

At present, the development of teaching reform program is not the result of multi-party consultation, to a greater extent, it is jointly developed by the teaching administrative personnel and the minority subject leaders, lacking of teaching teachers, students, social intermediary organizations and other stakeholders to participate in. In order to form a scientific and reasonable plan for the training of talents with all-round development and social needs, we must gradually establish and improve the multi-party consultation system for teaching reform. In the making process of teaching reform, it is to fully carry forward the spirit of democracy, according to the law of education and teaching development, the characteristics of subject, the orientation of social demand, the purpose of individual's all-round development to gradually form a teaching reform committee by experts and scholars in the related field, teaching management staff, teachers, students and social intermediary organizations and other stakeholders, which fully embodies the 
democratization, scientific and standardized development of teaching reform program.

\subsubsection{Strengthen the management system in teaching process}

The innovation of teaching management mechanism is another guarantee factor of teaching reform. To strengthen the management system in teaching process is to make an innovation for the focus on the results of the past management, change the "hard" results management for the "flexible" process management, which is more conducive to the overall growth of students. It needs the teaching management department according to the needs of teaching reform, to timely adjust the management objectives and content in teaching process, so that the concept of service as the guiding ideology to build a teaching management system. The new concept of teaching quality is as the standard to assess the quality of teaching. The flexible service concept is as the main means to manage students in order to promote the development of students' personality, strengthen students' awareness of self-learning, self-exploration, cooperative learning, and constantly cultivate and enhance students' sense of innovation and creativity, to provide a good, relaxed system environment and service support for the cultivation of diversified talents.

\section{Conclusions}

In short, the change of teaching mode is more difficult than to change the teaching content, teaching reform must break the teaching habits of teachers formed for a long time, master some unfamiliar new teaching techniques, more need to constantly update and improve their knowledge reserve. Teaching reform and innovation test of teachers' sense of social responsibility and executive ability of education, and teachers charged with " proselytizes instructs dispels doubt " mission, therefore, they must actively break the vicious circle of the examination to determine education, to break the bottleneck in teaching reform, dare to try to test and answer in the teaching reform and finally find an effective path for the cultivation of high-quality talent and innovative talents to make due contributions.

\section{References}

[1] Veal W R, Riley Lloyd M E, Howell M R, et al. Normative beliefs, discursive claims, and implementation of reform - based science standards[J]. Journal of Research in Science Teaching, 2016, 53(9):1419-1443.

[2] Feng T. Application of Virtual Starry Night Teaching Technology in Aesthetics Teaching[J]. International Journal of Emerging Technologies in Learning, 2016, 11(1):48-50.

[3] Nigam N, Boughanmi A. Can innovative reforms and practices efficiently resolve financial distress[J]. Journal of Cleaner Production, 2016, 140(1):1860-1871.

[4] Howell A. Firm R\&D, innovation and easing financial constraints in China: Does corporate tax reform matter[J]. Research Policy, 2016, 45(10):1996-2007.

[5] Gondi S, Patel K. Improving Rural Health: How system-level innovation and policy reform can enhance health outcomes across the United States[J]. IEEE Pulse, 2016, 7(6):8-12.

[6] Zgodavova K, Horvath M. Leading Innovation in Universities: From Practice Ahead of Practice[J]. Lecture Notes in Electrical Engineering, 2015, 312(1):479-484. 